\title{
DEVELOPMENT OF RELIGIOUS CHARACTERS AND ATTITUDES OF NATIONALISM IN SMP NEGERI 6 KOTA SALATIGA
}

\author{
Akhsin Rafika Dani \\ Program Studi Pendidikan Agama Islam IAIN Salatiga, Indonesia \\ Email:akhsinrafika@gmail.com
}

\begin{abstract}
This study aims to determine the pattern of fostering the religious character and attitude of nationalism of the students of SMP Negeri 6 Salatiga, the supporting and inhibiting factors and the connectivity between the two. This research is a qualitative research with a naturalistic descriptive approach. Data collection techniques using interview methods, observation and documentation. Character building in students uses exemplary, habituation, mau'izah, amtsal, tsawab and i'qab methods. The character building process has both inhibiting and supporting factors. Inhibiting factors in the form of funds used using independent funds, lack of student awareness and discipline, different student backgrounds, student human error, lack of provisions for learning to read and write Al-Quran, lack of controling from teachers, developments in science and technology such as gadgets or cellphones, there are figures that students fear and the covid-19 pandemic. Supporting factors are adequate school facilities, high student interest and direct assistance from teachers and counseling teachers. The results showed that the religious attitudes and attitudes of nationalism had an interrelated relationship with each other, where the religious character of the students was good, the attitude of nationalism was also good.
\end{abstract}

Keywords: Development, Religious Character, Nationalism Attitude.

\section{PEMBINAAN KARAKTER RELIGIUS DAN SIKAP NASIONALISME SISWA SMP NEGERI 6 KOTA SALATIGA}

\begin{abstract}
Abstrak
Penelitian ini bertujuan untuk mengetahui pola pembinaan Karakter Religus dan Sikap Nasionalisme Siswa SMP Negeri 6 Salatiga, faktor pendukung dan penghambat dan konektivitas diantara keduanya. Penelitain ini termasuk jenis penelitian kualitatif dengan pendekatan deskriptif naturalistik. Teknik pengumpulan data menggunakan metode wawancara, observasi dan dokumentasi. Pembinaan karakter pada siswa menggunakan metode keteladanan, pembiasaan, mau'izah, amtsal, tsawab dan i'qab. Proses pembinaan karakter memiliki faktor penghambat dan pendukung. Faktor penghambat berupa dana yang digunakan menggunakan dana mandiri, kurangnya kesadaran dan kedisiplinan siswa, latar belakang siswa yang berbeda-beda, human error siswa, kurangnya bekal pembelajaran baca tulis $\mathrm{Al}$ Quran, kurangnya controling dari guru, perkembangan dari IPTEK seperti gawai atau handphone, adanya figur yang ditakuti siswa dan adanya pandemi covid-19. Faktor pendukung berupa fasilitas sekolah yang memadai, minat siswa yang tinggi dan pendampingan langsung dari guru pengampu serta guru BK. Hasil penelitian menunjukkan bahwa sikap religius dan sikap nasionalisme tersebut memiliki hubungan yang saling berkaitan satu sama lain, dimana karakter religius siswa baik maka sikap nasionalismenya juga baik.
\end{abstract}

Kata Kunci: Pembinaan, Karakter Religius, Sikeap Nasionalism. PENDAHULUAN 
Perkembangan teknologi memberikan pengaruh globalisasi yang kuat dalam segala aspek bidang kehidupan. Hal itu memberikan dampak positif dan juga negatif, tergantung bagaimana cara menanggapi dan menggunakannya. Kuatnya pengaruh globalisasi menuntut masyarakat menyadari bahwa generasi bangsa terancam terbawa arus budaya yang tidak sesuai dengan jati diri bangsa. Ancaman tersebut salah satunya pada pembinaan karakter siswa. Pendidikan karakter merupakan suatu sistem penanaman nilai karakter kepada siswa meliputi beberapa komponen seperti pengetahuan, kesadaran atau kemauan dan tindakan untuk melaksanakan segala nilai-nilai yang diajarkan baik kepada Tuhan, diri sendiri, sesama makhluk ciptaan-Nya, lingkungan maupun kebangsaan agar menjadi manusia insan kamil (Narwanti, 2014).

Pendidikan karakter biasanya sudah terdapat dalam mata pelajaran. Mata pelajaran tersebut seperti PPKn. Pendidikan Pancasila dan Kewarganegaraan (PPKn) sebagai mata pelajaran wajib yang diajarkan di setiap sekolah mempunyai fungsi menanamkan nilai-nilai Pancasila kepada siswa. Penanaman nilai pancasila tersebut sebagai salah satu wujud dari pendidikan karakter. Namun dalam mengembangkan siswa yang berkarakter, pelajaran PPKn seolah-olah menjadi satu-satunya tumpuan. Hal tersebut berakibat kurang optimalnya penanaman karakter pada siswa sehingga membutuhkan daya dukung seluruh komponen sekolah. Terlepas dari PPKn sebagai sentral penanaman karakter, kurangnya penghayatan nilai-nilai pancasila juga menjadi masalah dalam penanaman karakter pada siswa (Amin, 2015).

Mata pelajaran PPKn saat ini tidak lagi menjadi sentral pendidikan karakter. Hal ini dikarenakan hadirnya kurikulum 2013 yang telah terintegrasi dengan pendidikan religius dimana dapat diterapkan tidak hanya pada lembaga pendidikan yang bernuansa agamis melainkan dapat diterapkan pada sekolah umum. Pendidikan religius menanamkan karakter religius kepada siswa sehingga siswa memiliki karakter yang religius. Karakter religius perlu ditanamkan dalam lingkungan pendidikan agar siswa mampu menumbuhkan perilaku sesuai dengan ajaran agama Islam yang berlandaskan Al-Quran dan Hadist.

Penerapan karakter regius tidak dapat terlepas dari sikap nasionalisme, dimana sikap nasionalisme menuntun siswa untuk menjunjung tinggi nilai kemanusiaan dan tenggang rasa. Nasionalisme merupakan kesadaran diri yang meningkat dengan diwujudkan oleh kecintaan yang melimpah pada negeri atau bangsa sendiri dan kadang disertai akibat mengecilnya arti juga sifat bangsa lain (Surono, 2017). Penanaman karakter religius dan sikap nasionalisme akan mampu menciptakan manusia insan kamil yang mampu menjunjung dan menjaga keutuhan bangsa dan negara. Sehingga, keduanya memegang peranan penting dan memiliki kesinambungan dalam menciptakan generasi berintegritas, bermoral dan berkemajuan.

Penerapan karakter religius dan sikap nasionalisme sangat bergantung pada pola pembinaan karakter. Hal ini telah diterapkan di Sekolah Menengah Pertama (SMP) Negeri 6 Kota Salatiga. Pola yang diterapkan dari pihak sekolah tidak menjadi satu-kesatuan melainkan menjalankan pola pembinaan secara terpisah.

Pola penerapan karakter religius di sekolah tersebut dapat dilihat dari: (1) Membaca al fatihah dan surat pendek sebelum memulai pembelajaran (tabfizdul qur'an), (2) Memberi salam dan berjabat tangan di pagi hari sewaktu murid-murid masuk sekolah (ta'dimul asatids), (3) Sholat dhuha berjamaah dan doanya (ibadah sholat sunnah). (4) Pembinaan jum'at religi membaca al qur'an bersama tiap hari 
jum'at pagi (tadarus qur'an). (5) Sholat zduhur dan sholat jum'at di masjid sekolah, (6) Memperingati hari besar islam seperti maulid nabi, tahun baru islam, idul adha/fitri, hari tasyrik, nuzulul qur'an, bulan romadhon dan semacamnya (a'yadul islamiyab). (7) Mengadakan kegiatan pengajian rutin dan acara yatiman. (8) Mengadakan kegiatan ekstra keagamaan seperti halnya rebana, kaligrafi, munasabaqoh tilawatil qur'an.

Pola penerapan sikap nasionalsme di sekolah dapat dilihat dari: (1) Progam sabtu bersih, dimana siswa sebelum masuk pembelajaran ada kegiatan gotong royong membersihkan lingkungan sekolah dengan tertib, (2) Menyanyikan lagu Indonesia raya 3 stanza diikuti seluruh warga sekolah dengan berdiri, (3) Pembinaan kegiatan ekstra kurikuler berupa pelatihan paskibra dan pramuka, (4) Mengadakan upacara bendera setiap hari senin, (5) Memperingati hari besar nasional yang diperingati sesuai dengan tatacara yang ada.

Hadirnya pola pembinaan karakter pada sekolah tersebut, memberikan suatu topik bahasan yang menarik untuk mengetahui lebih dalam mengenai pola pembinaan karakter religius dan sikap nasionalisme siswa/siswi SMP Negeri 6 Kota Salatiga tahun pelajaran 2019/2020.

\section{METODE}

Jenis penelitian ini menggunakan pendekatan kualitatif deskriptif. Penelitian ini menggunakan analisis data model Miles and Huberman, dimana terdapat tiga hal dalam analisis interaktif seperti reduksi data, penyajian data dan penarikan kesimpulan atau verifikasi (Nuroho, 2014). Waktu penelitian ini dilakukan selama tahun pelajaran 2019/2020 SMP Negeri 6 Salatiga. Kisaran waktu penelitian sejak tahun 2019 dimana peneliti PPL di SMP Negeri 6 Salatiga sampai 1 Oktober 2020. Sampel yang digunakan dalam penelitian ini menggunakan Purposive Sampling atau sampel bertujuan. Peneliti merupakan kunci utama di dalam keberlangsungan penelitian, karena penelitilah yang mengumpulkan seluruh data. Sehingga, instrumen dalam penelitian ini adalah peranan manusia (peneliti) itu sendiri.

Sumber data pada penelitian ini tergolong dalam ke dalam dua hal yakni sumber data primer dan sumber data sekunder. Data primer dalam penelitian ini diperoleh secara langsung dari sumbernya dengan menggunakan teknik wawancara, observasi dan dokumentasi dengan sumber dalam penelitian diantanya, Kepala Sekolah (satu orang), Guru Pendidikan Agama Islam (satu orang), Guru Bimbingan Konseling (satu orang), Guru Pendidikan Pancasila dan Kewarganegaraan (satu orang), Guru Ilmu Pengetahuan Sosial (satu orang) dan siswa SMP Negeri 6 Salatiga (lima orang). Data sekunder di dalam penelitian ini merupakan data pelengkap yang dibutuhkan yang diperoleh dari data yang sudah ada seperti dokumen (profil sekolah, dokumentasi segala bentuk kegiatan yang mendukung penelitian ini seperti kegiatan keagamaan dan kegiatan nasionalisme), arsip, jurnal harian dan berhubungan dengan permasalahan yang diteliti.

Pengumpulan data selalu disesuaikan dengan kondisi lapangan sehingga penelitian kualitatif tidak bersifat kaku. Antara peneliti dan data yang diteliti memiliki hubungan yang tidak dapat dipisahkan dan bersifat interaktif. Sedangkan dalam prosedur pengumpulan data dilakukan standarisasi dan menyatakan hubungan peneliti dengan yang diteliti bersifat independen dan tidak bisa dipisahkan antara satu sama lain (Suprayitno \& Sutinah, 2005). Berikut teknik pengumpulan data pada penelitian ini:

1. Observasi 
Observasi dilakukan secara langsung maupun tidak langsung dalam melakukan pengamatan terhadap suatu objek yang akan diteliti dengan menggunakan semua indera untuk memperoleh segala data yang dibutuhkan dalam penelitian (Agustinova, 2015). Tujuan observasi adalah untuk mengamati proses pembinaan karakter religius dan sikap nasionalisme, kegiatan dalam rangka membentuk karakter religius dan sikap nasionalisme, serta sikap dan perilaku siswa saat mengikuti kegiatan keagamaan dan nasional.

2. Wawancara

Wawancara yang dilakukan bersifat mendalam dan tidak struktur dimana pertanyaan disusun sesuai dengan keadaan dan ciri yang unik dari informan. Sehingga percakapan berlangsung mengalir apa adanya. Kisi-kisi wawancara yang dibuat oleh peneliti berupa poin-poin pokok yang akan ditanyakan pada informan dan akan dikembankan pada saat wawancara berlangsung.

\section{Tabel 1 Kisi-Kisi Wawancara}

\begin{tabular}{|c|c|c|}
\hline No. & Informan & Poin-poin pokok \\
\hline 1. & $\begin{array}{l}\text { Kepala } \\
\text { Sekolah }\end{array}$ & $\begin{array}{l}\text { a. Cara kepala sekolah dalam menumbuhkan karakter religius } \\
\text { dan sikap nasionalisme } \\
\text { b. Kegiatan yang diadakan untuk mendukung tumbuhnya } \\
\text { karakter religius dan sikap nasionalisme } \\
\text { c. Faktor pendukung dan penghambat dalam pembinaan } \\
\text { karakter religius dan sikap nasionalisme } \\
\text { d. Konektivitas antara karakter religius dan sikap nasionalisme }\end{array}$ \\
\hline 2. & Guru PAI & $\begin{array}{l}\text { a. Cara atau metode guru menanamkan karakter religius kepada } \\
\text { siswa } \\
\text { b. Proses guru menilai karakter religius sesuai dengan } \\
\text { indikatornya } \\
\text { c. Faktor pendukung dalam proses penanaman karakter religius } \\
\text { d. Kendala dalam menanamkan karakter religius } \\
\text { e. Solusi dari kendala dalam menanamkan karakter religius }\end{array}$ \\
\hline 3. & Guru BK & $\begin{array}{l}\text { a. Perilaku siswa yang menunjukkan karakter religius dan sikap } \\
\text { nasionalisme } \\
\text { b. Kegiatan yang diadakan untuk mendukung tumbuhnya } \\
\text { karakter religius dan sikap nasionalisme } \\
\text { c. Faktor pendukung dan penghambat dalam pembinaan } \\
\text { karakter religius dan sikap nasionalisme } \\
\text { d. Konektivitas antara karakter religius dan sikap nasionalisme }\end{array}$ \\
\hline 4. & Guru PPKn & $\begin{array}{l}\text { a. Cara atau metode guru menanamkan sikap nasionalisme } \\
\text { kepada siswa } \\
\text { b. Proses guru menilai sikap nasionalisme sesuai dengan } \\
\text { indikatornya } \\
\text { c. Faktor pendukung dalam proses penanamn sikap } \\
\text { nasionalisme } \\
\text { d. Kendala dalam menanamkan sikap nasionalisme } \\
\text { e. Solusi dari kendala dalam menanamkan sikap nasionalisme } \\
\text { f. Konektivitas antara karakter religius dan sikap nasionalisme }\end{array}$ \\
\hline
\end{tabular}




\begin{tabular}{|l|l|l|}
\hline 5. & Siswa & $\begin{array}{l}\text { a. Tanggapan siswa setelah mengikuti kegiatan keagamaan dan } \\
\text { kegiatan nasional }\end{array}$ \\
& $\begin{array}{l}\text { b. Makna kegiatan keagamaan dan kegiatan nasional menurut } \\
\text { siswa }\end{array}$ \\
& $\begin{array}{l}\text { c. Menanyakan mengenai } 6 \text { indikator sikap religius } \\
\text { d. Menanyakan mengenai } 7 \text { indikator nasionalisme } \\
\text { e. Tanggapan siswa mengenai metode dalam peroses pembinaan } \\
\text { karakter religius dan sikap nasionalisme }\end{array}$ \\
\hline
\end{tabular}

\section{Dokumentasi}

Dokumen merupakan teknik pengumpulan data dengan cara memperoleh informasi dari berbagai macam sumber tertulis atau segala bentuk dokumen yang dimiliki responden atau tempat, dimana responden melakukan kegiatan sehari-hari. Berikut daftar dokumen penelitian:

\section{Tabel 1.2 Daftar Dokumen Penelitian}

\begin{tabular}{|c|l|}
\hline No. & \multicolumn{1}{|c|}{ Dokumentasi } \\
\hline 1. & Profil sekolah \\
\hline 2. & Fasilitas sekolah \\
\hline 3. & $\begin{array}{l}\text { Segala bentuk kegiatan yang menunjang proses pembinaan karakter } \\
\text { religius dan sikap nasionalisme }\end{array}$ \\
\hline
\end{tabular}

\section{PEMBAHASAN}

Perkembangan karakter religius dan sikap nasionalisme dipengaruhi oleh proses pendidikan baik keluarga, lingkungan masyarakat juga lingkungan sekolah. Diberlakukannya kurikulum 2013 menuntut pengembangan sikap (afektif) yang lebih diutamakan. Sehingga pola pembinaan yang tepat mampu mebentuk karakter dan sikap nasionalisme pada diri siswa.

Pembinaan yang dilakukan sebagai upaya pembentukan sikap dan sifat agar terdapat sebuah perubahan yang lebih baik. Perkembangan arus globalisasi yang pesat menjadi salah satu tantangan untuk membentuk karakter siswa. Sehingga, dengan adanya pembinaan dalam pengembangan karakter religius dan sikap nasionalisme pada siswa SMP Negeri 6 Salatiga tujuan yang telah ditetapkan akan tercapai.

Pencapaian kualitas pendidikan dapat berjalan secara optimal perlu diupayakan bagaimana mengembangkan diri siswa untuk memiliki karakter religus dan sikap nasionalisme. Melalui proses pembinaan dalam lingkungan sekolah akan menjadikan manusia yang berkualitas dalam iman, ilmu dan mampu mengamalkan dalam kehidupan sehari-hari serta mampu menjadi manusia yang berkarakter baik yang mencintai tanah air Indonesia.

Pembinaan yang dilakukan dalam proses penanaman karakter religius dan sikap nasionalisme dilakukan dengan beberapa tahapan yaitu perencanaan, eksekusi, dan evaluasi di akhir semester yang mengedepankan kerjasama seluruh elemen pendidikan di sekolah. Proses tindakan pembinaan dilakukan dengan menggunakan berbagai metode, diantaranya sebagai berikut:

1. Metode keteladanan 
Metode ini dilakukan dengan menunjukkan perilaku terpuji kepada siswa SMP Negeri 6 Salatiga, tujuan yang akan dicapai dengan menggunakan metode ini adalah agar siswa senantiasa mengikuti segala tindakan terpuji. Hal ini menuntut pendidik menunjukkan perilaku tawadhu', sabar, jujur, ikhlas juga meninggalkan segala perilaku tercela. Usaha-usaha yang dilakukan guru SMP Negeri 6 Salatiga diantaranya adalah:

a. Guru memberikan contoh keteladanan dengan berpartisipasi secara aktif dalam kegiatan keagamaan dan kegiatan nasional

b. Guru memberikan contoh yang baik melalui sikap dan perilaku yang baik, sehingga antara teori dan praktiknya dapat berjalan dengan selaras

c. Didekatkan dengan syariat agama dan sikap rasa cinta kepada tanah air Indonesia

2. Metode pembiasaan

Metode ini dilakukan dengan membuat beberapa kegiatan yang mendukung dalam proses penanaman karakter religius dan sikap nasionalisme pada siswa SMP Negeri 6 Salatiga, agar siswa mampu membiasakan dirinya sesuai dengan kegiatan yang telah ditentukan. Usaha-usaha yang dilakukan di SMP Negeri 6 Salatiga untuk menanamkan karakter religius diantaranya adalah:

a. Berjabat tangan dengan guru waktu masuk sekolah dan mengucapkan salam sebagai bentuk sopan santun

b. Pelaksanaan sholat dhuha sebelum pembelajaran PAI dilanjutkan doa bersama dan mengahafal surat pendek guna menyandingkan dorongan spiritual siswa serta melatih hafalan dan bacaan siswa terhadap Al-Qur'an (Tahfizdul qur'an).

c. Pelaksanaan sholat dzuhur dan sholat jumat bersama untuk memupuk rasa solidaritas dan persaudaraan antar sesama

d. Pembinaan jumat religi dilakukan dengan membaca Al-Qur'an dilanjutkan membaca asmaul husna dan do'a bersama yang dilaksanakan di pagi hari guna menanamkan sikap religius

e. Peringatan hari besar islam (a'yadul islamiyah) yang diikuti oleh seluruh siswa SMP Negeri 6 Salatiga sebagai bentuk sikap toleransi

f. Pembinaa kegiatan ekstrakurikuler keagamaan seperti rebana, kaligrafi, munasabaqoh tilawatil qur'an dan SKI-BTQ sebagai wadah bagi siswa SMP Negeri 6 Salatiga yang belum bisa membaca Al-Quran dengan baik dan benar

g. Pelaksanaan infaq sebagai pelajaran arti dari sedekah dan peduli kepada sesama

Usaha-usaha yang dilakukan di SMP Negeri 6 Salatiga untuk menanamkan sikap nasionalisme diantaranya adalah:

a. Penekanan sikap disiplin kepada siswa SMP Negeri 6 Salatiga sebagai cara untuk menggiatkan sikap nasionalisme

b. Peringatan hari-hari besar nasionalisme dan upacara bendera setiap hari senin sebagai wujud hormat kepada para pahlawan yang telah menumpahkan penjajahan demi membela negara dari ancaman negara lain

c. Pelaksanaan festival budaya dengan pameran baju adat dan kesenian tari daerah sebagai wujud cinta terhadap budaya sendiri

d. Pelaksanaan program rutin etika moral setiap hari sabtu selesai pembelajaran yang terintegrasi dalam menjaga nama baik bangsa dan negara 
e. Menyanyikan lagu nasional 3 stanza sebelum pembelajaran dimulai sebagai wujud cinta kepada tanah air

f. Kegiatan bakti sosial seperti donasi pakaian layak pakai dan kegiatan sosial lainnya sebagai bentuk kepedulian terhadap sesama

g. Pelaksanaan program hemat air dan listrik

h. Pelaksanaan sabtu bersih berupa gotong royong untuk memupuk persatuan dan kesatuan

i. Pelaksanaan kegiatan ekstrakurikuler seperti paskibra, seni gamelan, drumb band dan pramuka

3. Metode mau'izah atau nasehat

Metode ini dilakukan dengan cara memerintah, melarang atau memperingatkan yang disertakan dengan motivasi dan imbal balik terhadap apa yang dilakukan oleh siswa SMP Negeri 6 Salatiga.

Usaha-usaha yang dilakukan guru SMP Negeri 6 Salatiga diantaranya adalah:

a. Guru memberikan teguran bagi siswa yang tidak mentaati pelaksanaan kegiatan yang berhubungan dengan penanaman karakter religius dan sikap nasionalisme

b. Pemberian nasehat dilakukan dengan kerjasama bersama kesiswaan dan BK

4. Metode amtsal atau perumpamaan

Metode ini dilakukan agar siswa SMP Negeri 6 Salatiga lebih mudah mencerna hal-hal yang sulit dan untuk meningkatkan tergugahnya perasaan siswa.

Usaha-usaha yang dilakukan guru SMP Negeri 6 Salatiga diantaranya adalah:

a. Guru memberikan sebuah istilah yang dengan mudah diingat dengan siswa, sehingga siswa mampu mengimplementasikan dalam kehidupan sehari-hari

5. Metode tsawab atau hadiah dan i'qab atau hukuman

Metode hadiah dan hukuman meupakan metode yang digunakan oleh SMP Negeri 6 Salatiga sebagai alat untuk meningkatkan kesadaran dan kehati-hatian. Harapannya agar siswa mampu termotivasi, sehingga akan melaksanakan semua kegiatan yang berhubungan dengan penanaman karakter religius dan sikap nasionalisme.

Usaha-usaha yang dilakukan guru SMP Negeri 6 Salatiga diantaranya adalah:

a. Penilaian terhadap karakter religius dan sikap nasional yang dilakukan oleh guru PAI dan PPKn akan membantu siswa bilamana terdapat nilai yang kurang. Hal ini sebagai pertimbangan kenaikan kelas

b. Pemberian hukuman dilakukan jika siswa melanggar ketentuan yang telah ditetapkan dalam kegiatan yang berkaitan dengan penanaman karakter religius dan sikap nasionalisme

c. Pemberian hukuman dilakukan dengan kerjasama bersama bagian kesiswaan dan BK

Proses pembinaan karakter memiliki faktor pendukung serta penghambat sehingga optimalisasi proses pembinaan dapat terhambat apabila faktor pendukung tidak sebanding dengan faktor penghambat. Proses pembinaan karakter religius dan sikap nasionalisme yang terlaksana terdapat beberapa fakor pendukung dalam menjalankan hal tersebut, diantaranya:

1. Adanya program-progam pembinaan dalam mengembangkan karakter religius dan sikap nasionalisme dengan sistem yang tertata 
2. Fasilitas sekolah yang memadai guna melancarkan proses kegiatan dalam penanaman karakter religius dan sikap nasionalisme pada siswa

3. Minat siswa yang tinggi dalam melaksanakan kegiatan yang berhubungan dengan penanaman arakter religius dan sikap nasionalisme

4. Pendampingan langsung oleh guru pengampu dan guru BK dalam melaksanakan program pembinaan karakter religius dan sikap nasionalisme

Disamping faktor pendukung, terdapat faktor penghambat dalam proses pembinaan karakter religius dan sikap nasionalisme, diantaranya adalah sebagai berikut:

1. Dana yang dialokasikan untuk kegiatan pembinaan karakter religius dan sikap nasionalisme pada siswa adalah dana mandiri, bukan dana bantuan seperti dana BOS

2. Kurangnya disiplin dan kesadaran siswa dalam mengikuti semua kegiatan dalam proses penanaman karakter religius dan sikap nasionalisme

3. Latar belakang siswa yang berbeda-beda, sehingga akan mempengaruhi karakter religus dan sikap nasionalisme

4. Beberapa siswa yang memiliki sikap human eror

5. Kurangnya bekal pembelajaran baca tulis Al-Quran dari beberapa siswa

6. Kurangnya controling dari guru dalam pelaksanaan kegiatan-kegiatan yang dilaksanakan, sehingga beberapa siswa masih ada yang membolos dalam kegiatan yang dilaksanakan

7. Perkembangan dari IPTEK seperti gawai atau handphone menghambat siswa cinta terhadap tanah air

8. Adanya figur yang ditakuti siswa, sehingga siswa memilih lari dari kewajibannya

9. Adanya pandemi covid 19, program-program yang dibentuk kurang bisa diimplementasikan

\section{SIMPULAN}

Hasil penelitian menunjukkan, pertama bahwa pola pembinaan terdiri dari perencanaan, pelaksanaan dan evaluasi sedangkan metode yang digunakan dalam pembinaan karakter religius dan sikap nasionalisme meliputi metode keteladanan, metode pembiasaan, metode mau'izah, metode amtsal, metode tsawab dan i'qab. Kedua, Faktor pendukung adanya program-progam pembinaan, fasiitas sekolah yang memadai, minat siswa yang tinggi dan pendampingan langsung oleh guru pengampu dan guru BK. Sedangkan faktor penghambatnya seperti dana yang digunakan menggunakan dana mandiri, kurangnya kesadaran dan kedisiplinan siswa, latar belakang siswa yang berbeda-beda, human eror siswa, kurangnya bekal pembelajaran baca tulis Al-Quran, kurangnya controling dari guru, perkembangan dari IPTEK seperti gawai atau handphone, adanya figur yang ditakuti siswa dan adanya pandemi covid-19.

\section{DAFTAR PUSTAKA}

Agustinova, D. E. (2015). Memahami Metode Penelitian Kualitatif. Yogyakarta: Calpulis.

Amin, M. M. (2015). Pendidikan Karakter Anak Bangsa. Yogyakarta: Calpulis.

Narwanti. (2014). Pendidikan Karakter. Yogyakarta: Familia.

Nuroho, K. S. (2014). Panduan Praktis Penelitian Kualitatif. Yogyakarta: Graha Ilmu.

Suprayitno, A., \& Sutinah. (2005). Metode Penelitian Sosial. Jakarta: Kencana.

Surono, K. A. (2017). PPenanaman Karakter dan Rasa Nasionalisme pada Kegiatan Ekstrakulikuler Pramuka di SMPN Singorojo Kabupaten Kendal. Indonesia Jurnal of Conservation, 23-30. 